\title{
Findings on Trends of Chromium and Lead Bioaccumulation in Cirrhina mrigala in the Water and Sediments of River Ravi
}

\author{
Muhammad Akram Qazi ${ }^{1 *}$, Hamda Azmat ${ }^{2}$, Noor Khan², Naveed Iqbal Khan ${ }^{1}$, \\ Farah Umar', Zubaida Hamid ${ }^{1}$, Rehman Gul' ${ }^{1}$, Mahreen Khalid ${ }^{1}$, Mahroze Fatima ${ }^{2}$, \\ Ayesha Malik², Sheeza Bano², Fakhira Khalid², Sadia Nazir ${ }^{2}$, \\ Muhammad Ijaz Mughal'2, Bakhtawar Baig ${ }^{2}$
}

${ }^{1}$ Soil Fertility Research Institute, Lahore, Agriculture Department, Punjab, Pakistan ${ }^{2}$ Department of Fisheries and Aquaculture, The University of Veterinary and Animal Sciences (UVAS), Lahore, Pakistan

Received: 6 February 2021

Accepted: 30 August 2021

\begin{abstract}
Water pollution requires constant analysis and revision of water resource policy at all levels. Unfortunately, waterways are polluted by illegal dumping of urban waste, industrial waste, and a variety of human activities. Hazardous releases from industry are harmful to both human and animal health and safety. The Ravi River is the largest river in Punjab, Pakistan, and its water quality has deteriorated as a result of the inflow of municipal and industrial waste. As a result of this pollution, the aquifer environment is deteriorating. This situation necessitates an assessment of the pollution level in the Ravi and its sediments in order to make an urgent and ecological arrangement to preserve and replenish the quality of the aquifer for long-term and safe use without interfering with the natural flow of the environment. Samples of fish (Cirrhina mrigala), water, and sediment from three public fishing sites in the Ravi River, Shahdra Bridge, Saggian Bridge, and Balloki Headworks, were collected on a monthly basis from October 2015 to March 2016 to detect metal concentrations. Physico-chemical parameters viz dissolved oxygen, temperature, $\mathrm{pH}$, and electrical conductivity were measured on the spot, while hardness, turbidity, and alkalinity were measured in the laboratory. The findings show that the highest concentrations of chromium $(\mathrm{Cr})$ and lead $(\mathrm{Pb})$ are present in water, fish organs, and river Ravi bed sediments at all three locations with statistically significant variations. $\mathrm{Pb}$ was slightly higher for all fish organs compared to $\mathrm{Cr}$. The highest concentration of chromium in water samples was found in October 2015, while the lowest concentration was detected in February 2016. The study concludes that all types of wastewater (sewage and agricultural waste) should be treated and tested for toxic heavy
\end{abstract}

e-mail: makramqazi@gmail.com 
metals such as $\mathrm{Cd}$ and $\mathrm{Pb}$ prior to discharge into aquatic resources. Finally, for the protection of aquatic life and to keep heavy metals out of the food chain, special attention must be paid to the enforcement of all applicable laws and regulations.

Keywords: Cirrhina mrigala, chromium (Cr), lead (Pb), Physico-chemical parameters, aquatic environment, Heavy Metals, Fish organs, accumulation

\section{Introduction}

Water is a big natural resource and a wonderful gift of nature to humanity used for the preservation of life and for general well-being [1]. It is used in agriculture, hydropower generation, livestock production, industrial activities, forestry, fisheries, navigation, and recreation [2]. In any region, surface and groundwater play an important role [3]. Water pollution is the contamination of water sources such as lakes, rivers, groundwaters, and oceans by anthropogenic activities [4]. Water pollution can be considered to be the presence of excessive quantities of a hazard (pollutants) in water in such a way that it is no longer appropriate for drinking, bathing, cooking, or other uses [5]. Water pollution is a major global concern requiring ongoing review and revision of water resource policy at all levels. Water shortages or pollution are caused worldwide by diseases and deaths of living creatures [6]. Unfortunately, river waters are contaminated by the unregulated dumping of waste, industrial waste, and a myriad of human activities, which affect their physical and chemical characteristics. Shifting of hazardous releases from industry is detrimental to human and animal health and safety [7]. To determine the level of heavy metal toxicity, it is important to consider the parameters of water quality [8]. Heavy metals $(\mathrm{Cr}$ and $\mathrm{Pb})$ may react with different contents of the aquatic environment and may be correlated with different geochemical phases of the sediment $[9,10]$. Aquatic species, including fish, absorb contaminants such as $\mathrm{Cr}$ and $\mathrm{Pb}$ directly from polluted water and indirectly through the food chain $[11,12]$.

Fish assimilate $\mathrm{Cr}$ and $\mathrm{Pb}$ through ingestion or gill uptake and accumulation in fish tissues, primarily liver, occurs at higher concentrations than all those metals present in the environment. The overall toxic effect on organs such as gill, kidney, and liver can have a significant effect on metabolic, physiological processes and could affect the growth and behavior of fish [13]. Speedy urbanization and industrial development increased the production of wastewater through sewage discharge. If wastewater goes in nearby rivers without suitable treatment, it causes many environmental issues for human beings and aquatic life. [14, 15] In other words, urbanization without justifiable development deteriorates the water ecosystem. Therefore, developing countries to implement proper urban water-quality management plans by installing wastewater treatment facilities at disposal sites. However, many cities in developing countries have been urbanized without such planning, therefore this contaminated water from residential and industrial areas contaminate the water ecosystem. [16]. The main objective of this study was therefore to investigate the effect of $\mathrm{Cr}$ and $\mathrm{Pb}$ on the survival of Cirrhins mrigala and to compare $\mathrm{Cr}$ and $\mathrm{Pb}$ concentrations in different fish tissues such as muscle, skin, and gill. While the natural influx of the River Ravi decreases over time, industrial, animal waste, and municipal wastewater are continuously dumped into the river without treatment, affecting the wastewater dilution process and contributing significantly to water pollution.

\section{Materials and Methods}

This study was carried out by the Research Laboratory, the Department of Fisheries and Aquaculture, the University of Veterinary and Animal Sciences, Lahore (Ravi Campus, Pattoki). Water, sediment, and fish (Cirrhina mrigala) were collected monthly for the period from October 2015 to March 2016. Samples were obtained from three public fishing sites in River Ravi Viz. Shahdra Bridge, Saggian Bridge, Balloki Headworks. Two sites (upstream and downstream) were selected for sampling at all locations. Physico-chemical parameters vz. Dissolved oxygen, temperature, $\mathrm{pH}$, and electrical conductivity were measured on the spot, while hardness, turbidity, and alkalinity were measured in Laboratory.

\section{Collection and Preparation of Water Samples}

Water samples were collected every month from October to March between 6 a.m. and 6 p.m. Water samples were obtained from just below the surface and the column (one meter below the surface) using the Kemmerer bottles. $10 \mathrm{ml}$ of concentrated $\mathrm{HNO}_{3}$ was added to the sample taken in the beaker and stirred for 10 minutes, filtered, and kept at room temperature for further analysis of heavy metals.

\section{Sediments Sample Collection and Preparation}

River bed sediments were collected monthly with the use of a Grab Sampler. Polyethylene scoops and cans have been used for sampling and storage. Samples were packed in ice bags during transport to the laboratory. After diligent air-drying, meticulous sieving was carried out using a $2 \mathrm{~mm}$ sieve. Pulverized sediment samples were packed in pre-marked polyethylene zipper bags 
and stored below $-20^{\circ} \mathrm{C}$. The sample was prepared using an aqua-regia extraction method and approximately 3 grams were taken in a $250 \mathrm{ml}$ glass beaker in this technique. Metal digestion was conducted at chamber temperature for approximately 16 hours using $28 \mathrm{ml}$ of 30 percent Hydrochloric Acid $(\mathrm{HCl})$ and 70 percent Nitric Acid $\left(\mathrm{HNO}_{3}\right)$ at a 3:1 ratio and was combined to prepare the aqua regia. The suspension thus obtained was again digested by heating at around $130^{\circ} \mathrm{C}$ for 2 hours. In the second stage of digestion, the heating was done in the water bath. As a result, the suspension was tested and sieved using What's man filter paper and then diluted by making up a volume of up to $100 \mathrm{ml}$ with $0.5 \mathrm{M} \mathrm{HNO}_{3}$. Prepared sediment samples were then stored at $4^{\circ} \mathrm{C}$ for heavy metal estimation.

\section{Fish Sample Collection and Digestion}

Cirrhina mrigala samples were collected from three River Ravi sites monthly. Cirrhina mrigala was collected from the sampling site by netting. Five specimens of the species were collected during each sample with an average weight of $800-1000 \mathrm{gm}$ and the fish was preserved at $4^{\circ} \mathrm{C}$ right after capturing the fish and immediately transported to the laboratory premises where they were frozen using cooling chest boxes. The fish samples were then carefully removed to obtain the required vital organs (Gills, Liver, Skin, and Muscle) under examination. At this stage, individual fish was properly washed and cleaned using distilled water to remove any remains of rubble, hummus, plankton, or additional peripheral adherent matter. After a weight of $2.0 \mathrm{~g}$ of each organ or whole organ (pre-weighed in case of the liver) was weighed, dried in the oven at $65^{\circ} \mathrm{C}$ for approximately 24 hours. After this time, the next step was to burn it to ashes in the furnace at $700-1000^{\circ} \mathrm{C}$ for approximately 90 minutes. Following this step, the ash content obtained from the organ is dissolved in $18 \mathrm{ml}$ of Conc. $\mathrm{HNO}_{3}$ was then heated again for two hours. The last step was to add $10-15 \mathrm{ml}$ of double distilled water and then make- up to $50 \mathrm{ml}$ of volume by adding double de-ionized water.

\section{Determination of $\mathrm{Cr}$ and $\mathrm{Pb}$}

Z-8230 Polarized Zeeman Atomic Absorption Spectrophotometer was used to estimate $\mathrm{Cr}$ and $\mathrm{Pb}$ in water, sediment, and Cirrhina mrigala organs (liver, gills, muscle and skin) (liver, gills, muscle, and skin).

\section{Results and Discussion}

\section{Physico-Chemical Parameters}

At the site, physical-chemical parameters such as dissolved oxygen, (a portable dissolved oxygen analyzer (determinator) was used to determine the dissolved oxygen concentration), temperature, (a thermometer was used to determine the water temperature), $\mathrm{pH}$, and electrical conductivity, ( $\mathrm{pH}$ and EC were measured using a portable $\mathrm{pH}$ and $\mathrm{EC}$ meter), and hardness, (hardness of water was determined using the EDTA Titration Method) were measured. Sulfuric acid is added to the water sample in a measured amount until the three major forms of alkalinity (bicarbonate, carbonate, and hydroxide) were converted to carbonic acid. Table 1 contains data on all physico-chemical parameters.

\section{$\mathrm{Cr}$ and $\mathrm{Pb}$ Concentration $\left(\mathrm{mg} \mathrm{L}^{-1}\right)$ in Water}

The concentration of chromium in the water samples (upstream and downstream) obtained from all three experimental sites (Table 2) shows that the highest concentration of chromium is present in Balloki Headworks water followed by Shahdara Bridge and Saggian Bridge with mean values of $58.70 \pm 3.27$, $43.23 \pm 9.08$, and $41.35 \pm 3.28 \mathrm{mgL}^{-1}$ respectively. This indicates that the highest contamination of chromium in Balloki Head has occurred between the three experimental sites. This table also shows major seasonal variations in data. The maximum concentration was observed during October 2015 (55.55 $\left.\pm 9.48 \mathrm{mg} \mathrm{L}^{-1}\right)$, while the minimum concentration was observed during January 2016 (43.33 $\left.\pm 8.79 \mathrm{mg} \mathrm{L}^{-1}\right)$. In the $\mathrm{Pb}$ evaluation, between the three sampling sites, the water at Baloki Head Works also showed significantly higher toxicity of $\mathrm{Pb} 0.20 \mathrm{mg} \mathrm{L}^{-1}$ both at upper and downstream followed by that at Shahdara, Saggian Bridge with mean concentrations respectively, with statistically nonsignificant differences (Table 2).

\section{Chromium and Lead Concentration $(\mu \mathrm{g} / \mathrm{g})$ in Bed Sediments}

Bed sediments are usually the final pathway of both natural and anthropogenic components generated or extracted from the environment. Sediment content is a good measure of water column contamination, where it appears to concentrate heavy metals and other organic contaminants. The drainage water brings large quantities of sediments to rivers, lakes, etc., which are dispersed across the entire body of water through tides and movement of water. In this analysis, the samples of bed sediment were obtained from the study area during the study period from October 2015 to March 2016 and the concentration of $\mathrm{Cr}$ was shown in Table 3. In the present analysis, the highest concentration was observed at Balloki Headworks with mean values of $141.35 \pm 14.46 \mu \mathrm{g} / \mathrm{g}$ followed by Shahdara Bridge and Saggian Bridge with mean values of $123.25 \pm 13.03$ and $97.23 \pm 17.88 \mu \mathrm{g} / \mathrm{g}$, respectively. The $\mathrm{Pb}$ concentration in the soil bed of the three sampling sites Shahdara Bridge, Saggian Bridge, and Balloki Headworks at river Ravi was reported with remarkable ranges. The Average value of $\mathrm{Pb}$ at three stations Shahdara Bridge, Saggian Bridge, and Balloki Headworks was documented 


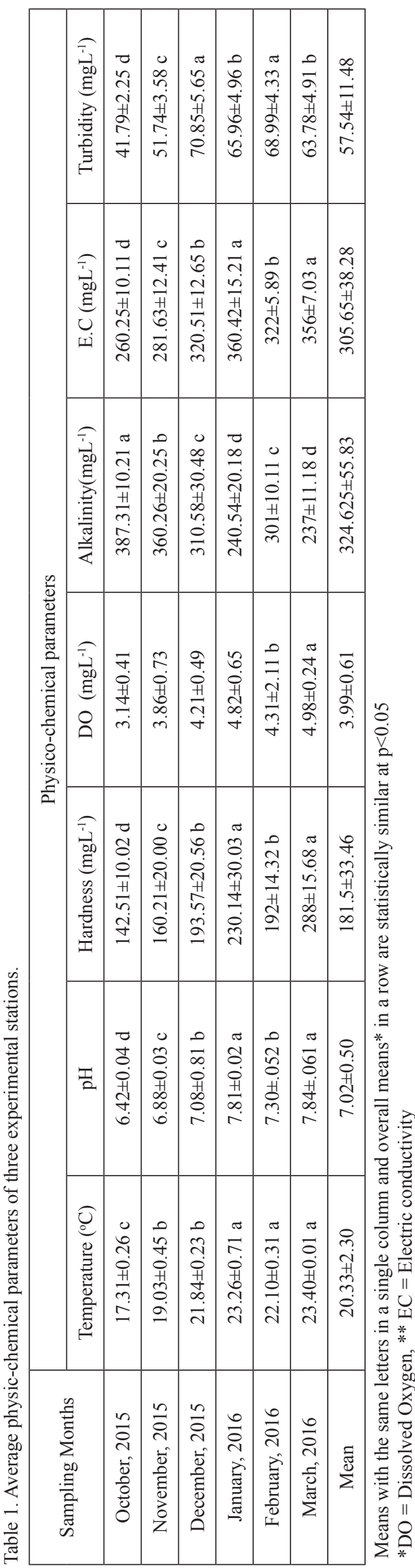

as $70.24 \pm 11.33,81.2325 \pm 14.18$, and $129.5 \pm 3.10 \mu \mathrm{g} / \mathrm{g}$, respectively (Table 3 ).

\section{$\mathrm{Cr}$ and $\mathrm{Pb}$ Concentration $\left(\mathrm{mg} \mathrm{L}^{-1}\right)$ in Fish Organs (Cirrhina mrigala)}

Fish (Cirrhina mrigala) was collected from three sampling sites. Shahdara Bridge, Sggian Bridge, and Balloki Headworks for the months from October 2015 to March 2016. $\mathrm{Cr}$ and $\mathrm{Pb}$ concentrations were measured in the liver, muscle, skin, and gills of all fish collected through the Atomic Absorption Spectrophotometer. The fish organs showed major variable responses in terms of metal accumulation. $\mathrm{Pb}$ was significantly higher with all fish organs, preceded by Cr. At Shahdara Bridge, Cirrhina mrigala displayed a significantly variable response in terms of metal accumulation in its organs. The highest concentration of $\mathrm{Cr}$ was observed in the liver, while the minimum concentration was observed in fish skin with mean values of $20.66 \pm 1.51$ and $0.40 \pm 0.09 \mu \mathrm{g} / \mathrm{g}$, respectively (Table 4) at Shahdra Bridge. Same trend was observed at head Saggian $(18.87 \pm 1.84,1.19 \pm 0.08 \mu \mathrm{g} / \mathrm{g})$ (Table 4) and head Baloke (35.09 $\pm 1.17,2.33 \pm 0.22 \mu \mathrm{g} / \mathrm{g}$ ) (Table 4). Different fish organs of Cirrhinus mrigala containing different amounts of $\mathrm{Pb}$. The concentration of $\mathrm{Pb}$ in the gill observed higher and lowest concentration was observed in the skin at Shahdra Bridge 0.18 $\pm 0.06,0.10 \pm 0.10 \mu \mathrm{g} / \mathrm{g}$ respectively (Table 5). At Saggian Bridge liver contained the highest concentration of $\mathrm{Pb}(0.28 \pm 0.17 \mu \mathrm{g} / \mathrm{g})$ and $\mathrm{a}$ minimum concentration of $0.14 \pm 0.16$ was found in the skin as compared to other organs (Table 5). The same trend was observed in liver and skin at Baloke Bridge $0.34 \pm 0.18$ and $0.15 \pm 0.09 \mu \mathrm{g} / \mathrm{g}$ (Table 5).

Heavy metals are extreme aquatic pollutants, and their uptake and accumulation in the aquatic environment will have a direct impact on the aquatic food chain and eventually on humans. Water bodies are vital natural resources to meet the increased human needs for fish. The contamination of the river is primarily caused by the discharge of effluents from factories and municipal wastewater. As a result, water pollution has become more serious due to its effects on human health and the protection of aquatic ecosystems. The awareness of heavy metal concentrations in fish as well as in water and sediments is therefore significant in terms of the essence of the management and human consumption of fish. In this study, a high concentration of heavy metal chromium was observed in water collected from the main sites of Shahdra Bridge, Saggian Bridge, and Balloki from October 2015 to March 2016. During this analysis, the highest concentration of $\mathrm{Cr}$ in water samples was detected in October 2015, while the lowest concentration of $\mathrm{Cr}$ was detected in February 2016.

Physico-chemical parameters of the water sample have also been assessed, as changes in parameters also influence aquatic life. Water temperatures can cause differences in the metal deposition in different 
Table 2. $\mathrm{Cr}, \mathrm{Pb}$ concentration $\left(\mathrm{mgL}^{-1}\right)$ in water of all three experimental stations.

\begin{tabular}{|c|c|c|c|c|c|c|}
\hline \multirow{2}{*}{ Month } & \multicolumn{2}{|c|}{ Shahdra Bridge $\left(\mathrm{mgL}^{-1}\right)$} & \multicolumn{2}{c|}{$\begin{array}{c}\text { Saggian Bridge } \\
\left(\mathrm{mgL}^{-1}\right)\end{array}$} & \multicolumn{2}{c|}{ Balloki Headworks $\left(\mathrm{mgL}^{-1}\right)$} \\
\cline { 2 - 7 } & $\mathrm{Cr}$ & $\mathrm{Pb}$ & $\mathrm{Cr}$ & $\mathrm{Pb}$ & \multicolumn{2}{c|}{$\mathrm{Cr}$} \\
\hline October,15 & 59.03 & 0.07 & 44.82 & 0.025 & 62.80 & 0.025 \\
\hline November,15 & 46.77 & 0.105 & 44.82 & 0.06 & 61.50 & 0.05 \\
\hline December,15 & 44.26 & 0.15 & 40.33 & 0.085 & 56.99 & 0.065 \\
\hline January,16 & 38.76 & 0.025 & 37.76 & 0.21 & 53.46 & 0.285 \\
\hline February,16 & 34.31 & 0.21 & 40.37 & 0.21 & 58.59 & 0.4 \\
\hline March,16 & 36.22 & 0.235 & 39.99 & 0.195 & 59.17 & 0.39 \\
\hline $\begin{array}{c}\text { overall Means } \\
\pm \text { SD }\end{array}$ & $43.23 \pm 9.08 \mathrm{~b}$ & $0.130 \pm 0.09 \mathrm{c}$ & $41.35 \pm 2.85 \mathrm{c}$ & $0.140 \pm 0.09 \mathrm{~b}$ & $58.70 \pm 3.28 \mathrm{a}$ & $0.200 \pm 0.19 \mathrm{a}$ \\
\hline
\end{tabular}

Means with the same letters in a single column and overall means* in a row are statistically similar at $\mathrm{p}<0.05$

Table 3. Concentration of $\mathrm{Cr}, \mathrm{Pb}(\mu \mathrm{g} / \mathrm{g})$ in bed sediments collected from three sampling stations during study period.

\begin{tabular}{|c|c|c|c|c|c|c|}
\hline \multirow{2}{*}{ Month } & \multicolumn{2}{|c|}{ Shahdra Bridge $(\mu \mathrm{g} / \mathrm{g})$} & \multicolumn{2}{|c|}{ Saggian Bridge $(\mu \mathrm{g} / \mathrm{g})$} & \multicolumn{2}{|c|}{ Balloki Headworks $(\mu \mathrm{g} / \mathrm{g})$} \\
\cline { 2 - 7 } & $\mathrm{Cr}$ & $\mathrm{Pb}$ & $\mathrm{Cr}$ & $\mathrm{Pb}$ & $\mathrm{Cr}$ & $\mathrm{Pb}$ \\
\hline November,15 & 121.78 & 82.23 & 107.34 & 99.78 & 143.59 & 131 \\
\hline December,15 & 134.24 & 75.55 & 89.54 & 65.54 & 165.87 & 128 \\
\hline January,16 & 142.38 & 67.23 & 75.37 & 81.96 & 137.23 & 133 \\
\hline February,16 & 121.34 & 55.95 & 81.34 & 77.65 & 123.34 & 126 \\
\hline Means \pm SD & $129.94 \pm 13.03 \mathrm{~b}$ & $70.24 \pm 11.33 \mathrm{c}$ & $88.40 \pm 17.88 \mathrm{c}$ & $81.2325 \pm 14.18 \mathrm{~b}$ & $142.51 \pm 14.46 \mathrm{a}$ & $129.5 \pm 3.10 \mathrm{a}$ \\
\hline
\end{tabular}

Means with the same letters in a single column and overall means* in a row are statistically similar at $\mathrm{p}<0.05$

organs. Higher temperatures promote the accumulation of chromium, especially in the most heavily burdened organs: the kidneys and the liver. Water hardness (mainly calcium concentration) also influences the absorption of metals through the gill epithelium. In this study, the temperature falls from October 2015 to January 2016 and increases in February and March 2016, pH, dissolved oxygen, hardness, alkalinity, electrical conductivity, and turbidity also differ from month to month for all three stations. The highest alkalinity concentration was observed in October 2015 and the lowest concentration was observed in January 2016. Electrical conductivity was higher in March 2016. The highest turbidity level was recorded in December 2015 and the lowest was recorded in October 2015. [17] also determined Physico-chemical parameters for different seasons. They showed that Physico-chemical parameters were within the most desirable limits for all seasons except $\mathrm{pH}$ in summer, total alkalinity and $\mathrm{Fe}$ content in spring, autumn, and winter; total dissolved solids in winter and turbidity in all seasons.

During this analysis, sediment samples from Shahdra Bridge, Saggian, and Balloki Headworks were collected every month from October 2015 to March 2016 to detect metal concentrations. In this analysis, a higher level of chromium was found in the sediment sample in December 2015. The lowest amount of chromium was present in January 2016. [18] also found higher concentrations of $\mathrm{Fe}$ compared to nine heavy metals $\mathrm{Cd}, \mathrm{Cr}, \mathrm{Co}, \mathrm{Cu}, \mathrm{Fe}, \mathrm{Mn}, \mathrm{Pb}$ and $\mathrm{Zn}$, also found lower $\mathrm{Cd}$ in fish. [19] detected higher concentrations of $\mathrm{Mn}$ in sediments, than $\mathrm{Cr}, \mathrm{Cd}, \mathrm{As}, \mathrm{Ni}$ and $\mathrm{Pb}$. [20] found a higher degree of $\mathrm{Fe}$ between $\mathrm{Zn}, \mathrm{Cu}, \mathrm{Cr}$, and $\mathrm{Ni}$.

The concentration of chromium in Cirrhinus mrigala was found in this research and demonstrated in various fish organs such as the liver, muscle, skin, and gill. It is indeed [21] also said fish bio-accumulate heavy metals, including $\mathrm{Cd}$, zinc, lead, and copper, through various organs such as the liver, gill stomach and intestine. [22] examined the bioaccumulation of heavy metals including cadmium, chromium, copper, iron, lead, zinc, manganese, and mercury in the livers of Cirrhinus mrigala. They found that the bioaccumulation amount of zinc was higher than that of metals. Among the fish species, the accumulation of $\mathrm{Cd}, \mathrm{Cr}, \mathrm{Cu}, \mathrm{Zn}, \mathrm{Mn}, \mathrm{Ni}$, and $\mathrm{Hg}$ was highest in Cirrina mrigala while low in Catla Catla, except for $\mathrm{Cr}$ and $\mathrm{Fe}$. [23] determined the concentration of six edible fish in muscle, liver, and gill. The highest concentration of As was found in the liver and the lowest concentration was found in gills. 


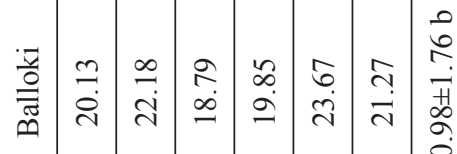

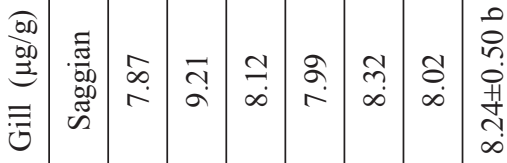

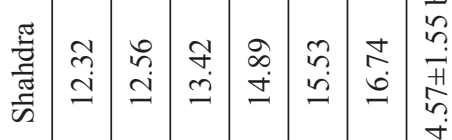

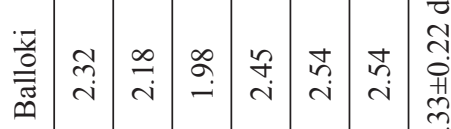

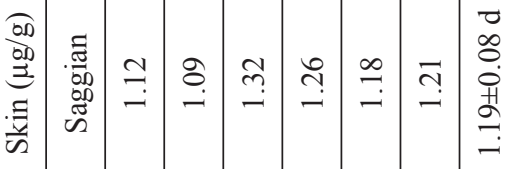

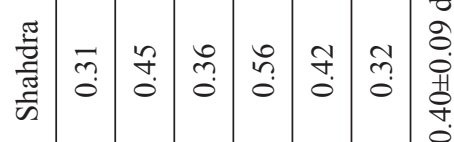

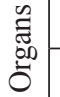

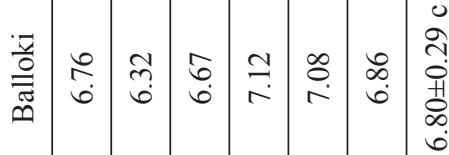

毠

:

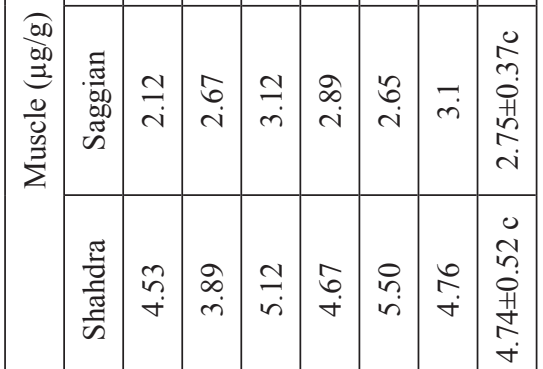

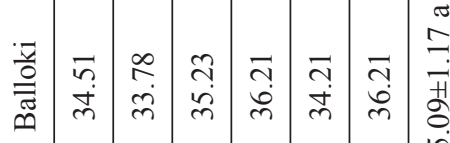

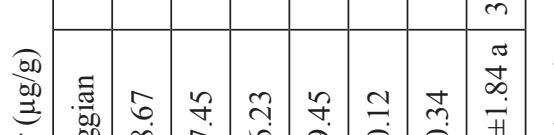

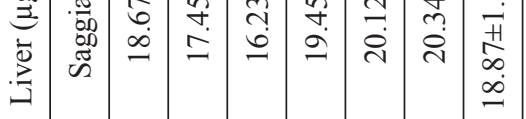

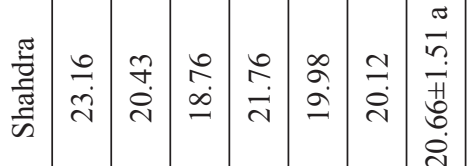

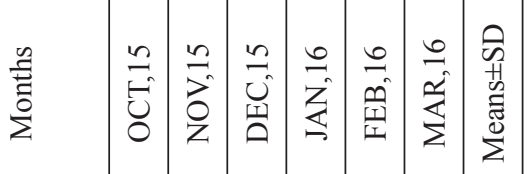

\begin{tabular}{|c|c|c|c|c|c|c|c|c|c|}
\hline & \multirow{3}{*}{ 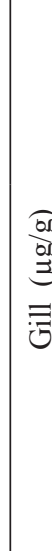 } & \begin{tabular}{|l}
$\frac{\vec{y}}{0}$ \\
$\overline{\bar{J}}$ \\
$\ddot{\mathscr{N}}$
\end{tabular} & ઼ָ & กิ & $\stackrel{2}{\circ}$ & $\underset{\sigma}{\vec{f}}$ & ñ & â. & $\begin{array}{l}0 \\
0 \\
0 \\
0 \\
0 \\
0 \\
0 \\
0 \\
0\end{array}$ \\
\hline & & 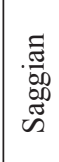 & $\stackrel{0}{0}$ & $\stackrel{f}{\circ}$ & 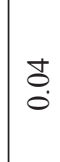 & ֶิ & $\stackrel{2}{0}$ & กิ & $\begin{array}{l}\overrightarrow{0} \\
0 \\
0 \\
0 \\
0 \\
\hat{n} \\
0\end{array}$ \\
\hline & & 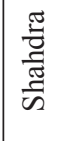 & $\hat{\widehat{̣}}$ & กิ & $\stackrel{n}{0}$ & $\frac{n}{0}$ & $\stackrel{1}{0}$ & $\stackrel{ \pm}{0}$ & \begin{tabular}{|l}
0 \\
0 \\
0 \\
01 \\
0 \\
0 \\
0
\end{tabular} \\
\hline & \multirow{3}{*}{ 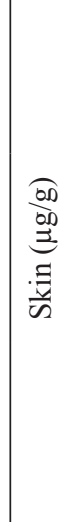 } & 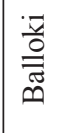 & $\hat{\widehat{̣}}$ & ๙ิ & $\widetilde{\sim}$ & oे. & $\stackrel{n}{0}$ & Oे. & $\mid \begin{array}{l}a \\
0 \\
0 \\
n \\
0 \\
0\end{array}$ \\
\hline & & 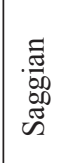 & ô. & 官 & ֶิ & 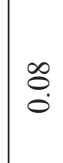 & $\overrightarrow{0}$ & ? & $\begin{array}{l}\vec{z} \\
0 \\
0 \\
0 \\
+0 \\
0 \\
0\end{array}$ \\
\hline & & 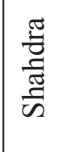 & $\begin{array}{l}0 \\
0 \\
0\end{array}$ & of & ठ̊. & Oे & ָ̃ & ปั & $\begin{array}{l}0 \\
0 \\
0 \\
0 \\
01 \\
0 \\
0 \\
0\end{array}$ \\
\hline & \multirow{3}{*}{$\begin{array}{l}\frac{\partial D}{\partial D} \\
\overrightarrow{3} \\
\frac{0}{U} \\
\overrightarrow{0} \\
\sum\end{array}$} & 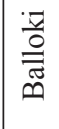 & $\frac{n}{0}$ & $\stackrel{m}{0}$ & ปิ & $\frac{a}{0}$ & $\overrightarrow{0}$ & $\stackrel{9}{0}$ & $\begin{array}{l}0 \\
0 \\
0 \\
0 \\
0 \\
0 \\
0 \\
0\end{array}$ \\
\hline & & 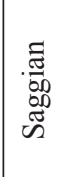 & $\stackrel{\partial}{0}$ & ¿. & ob & $\stackrel{\text { Tे }}{0}$ & $\tilde{\hat{o}}$ & సิ & $\begin{array}{l}0 \\
n \\
0 \\
0 \\
0 \\
0 \\
0\end{array}$ \\
\hline & & 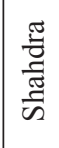 & $\stackrel{m}{0}$ & $\overrightarrow{0}$ & $\stackrel{0}{0}$ & $\stackrel{2}{\circ}$ & o̊ & ? & 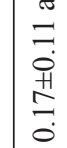 \\
\hline & \multirow{3}{*}{ 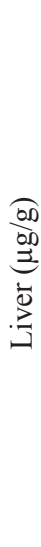 } & $\frac{\vec{y}}{\stackrel{\underline{0}}{\bar{J}}}$ & ñ & ?̊ & $\stackrel{t}{0}$ & $\stackrel{\infty}{\text { ஸे }}$ & $\frac{n}{0}$ & $\stackrel{7}{0}$ & $\begin{array}{c}\infty \\
\infty \\
0 \\
0 \\
+1 \\
0 \\
0\end{array}$ \\
\hline & & 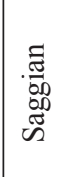 & ஸ̃ & ڤి & $\stackrel{7}{0}$ & f & in & $\stackrel{0}{0}$ & 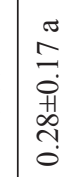 \\
\hline & & 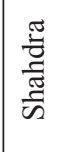 & $\stackrel{t}{0}$ & ?ొ? & $\stackrel{0}{0}$ & $\stackrel{5}{0}$ & $\stackrel{\circ}{\circ}$ & $=$ & $\begin{array}{c}\tilde{J} \\
\simeq \\
0 \\
0 \\
0 \\
0 \\
0\end{array}$ \\
\hline & $\stackrel{\tilde{E}}{\tilde{E}^{n}}$ & & 公 & $\begin{array}{l}n \\
\vec{z} \\
z\end{array}$ & $\begin{array}{l}n \\
\tilde{u} \\
\underline{y}\end{array}$ & 足 & 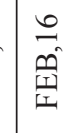 & 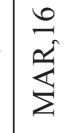 & $\begin{array}{l}n \\
0 \\
0 \\
0 \\
\text { ह } \\
\Sigma\end{array}$ \\
\hline
\end{tabular}


The concentration of heavy metal $\mathrm{Cu}, \mathrm{Zn}, \mathrm{Pb}, \mathrm{Fe}, \mathrm{Mn}$ in the liver muscle gills was found by [24] and the highest accumulation in the liver was assessed. [25] determined the concentration of lead, cadmium, and chromium, and copper in the liver, gills, kidneys, and muscles of eight edible fish species. There was a greater concentration of metal in the liver organs, followed by gills, kidneys, and muscles. [26] determined that Labeo rohita had high chromium contents compared to Cirrhihus mrigala and Catla Catla. Among organs, the liver and kidney displayed higher tendencies. [27] assessed the acute toxicity of Aluminum in Catla Catla and Cirrhinus mrigala. They said among the three fish species, Catla Catla was more sensitive to Al. [28] observed the toxic effects of nickel and chromium on bone tissue and the edible fish species Cirrhimus mrigala. They have shown that there is a significant change in the content of bone minerals that is more pronounced in nickel than in chromium. [29] also found the accumulation of chromium in the tissue of Cirrhinus mrigala. They showed maximum accumulation of chromium in the liver and kidney while minimum accumulation was in gills. Additionally, this is an ongoing study, and additional research is necessary to draw valuable conclusions. Using polluted water modelling, determine the factors that contribute to deteriorating water quality and recommend ways and means to replenish the water reservoir in order to alleviate increasing stress on River water. Additional detailed/close monitoring of the wastewater levels quality should be installed in order to more precisely quantify various parameters. And pretreatment of industrial and urban effluents prior to disposal in the River

\section{Conclusion}

The concentrations of $\mathrm{Cr}$ and $\mathrm{Pb}$ in three sampling sites in the River Ravi (Punjab, Pakistan), were analyzed in the study project. It is abundantly clear that heavy metals such as $\mathrm{Cr}$ and $\mathrm{Pb}$ have been found in higher concentrations in the water (Critical Limits) and had produced an accumulation in various fish organs. (Liver) This would eventually have an effect not only on the enzyme and genetics of Cirrhina mrigala but also on the living organisms that consume it as a food source. It is recommended, based on findings, that all forms of wastewater (sewage and agricultural waste) be treated and should be free of toxic metals before discharge into the aquatic environment. Last but not least, attention must be given to the enforcement of all provisions of laws and regulations relating to the safety of aquatic ecosystems. The study can be expanded to include other aquatic life found in the river, as well as a method for determining the most costeffective ways to replenish water resources at the pilot scale and their application in the field or large reservoir of water.

\section{Acknowledgments}

The authors are grateful to Hafiz Hussnain Barkat Qazi, Sidra Qazi, Muntaha Qazi and Marfowa Qazi for their assistance especially in writing the manuscript.

\section{Conflict of Interest}

The authors declare no conflict of interest.

\section{References}

1. BERGSTROSM J.C., RANDALL A. Resource Economics. An Economic Approach to Natural Resources and Environmental Policy, $4^{\text {th }}$ ed.; Edward Elgar: Cheltenham, UK, 2016.

2. SINGH M., SINGH R., BHODORIYA P.B.S., SHINDE V., MISHRO A., NARWADE A.V., PRADHAN S. Integration with remote sensing and GIS catchment scale hydrological modeling in middle reach of Mahanadia river basin using Simplified Coefficient model. National Academic of Agricultural science 34 (7), 2011, 2016.

3. McMAHON P.B, BELITZ K, REDDY J.E., JOHNSON T.D. Elevated Manganese Concentrations in United States Groundwater, Role of Land Surface-Soil-Aquifer Connections Environ. Sci. Technol. 53, 29, 2019.

4. SCHWEITZER L., NOBLET J. Water contamination and pollution Green Chemistry, Elsevier. 261, 2018.

5. OLANIRAN N.S. Environment and Health: An Introduction. Olaniran, N.S. et al (Ed) Environment and Health. 1995.

6. KORTELING B., DESSAI S., KAPELAN Z. Using information-gap decision theory for water resources planning under severe uncertainty. Water Resour. Manag. $1,2012$.

7. ADEKUNLE A.S. ENIOLA I.T.K. Impact of industrial effluents on quality of segment of Asa River within an industrial estate in Ilorin, Nigeria.NY Sci. J. 1 (1), 17, 2008.

8. KURNAZ A., MUTLU E., AYDIN UNCUMUSAOĞLU A. Determination of water quality parameters and heavy metal content in surface water of Çiğdem Pond (Kastamonu/Turkey) Turkish Journal of Agriculture Food Science and Technology, 4 (10), 907, 2016.

9. AMBREEN F., JAVED M. Assessment of acute toxicity of pesticides mixtures for Cyprinus carpio and Ctenopharyngodon idella. Pak. J. Zool. 47, 133, 2015.

10. MORILLO J., USERO J., GRACIA I. Heavy metal distribution in marine sediments from the southwest coast of Spain. Chemosphere. 55 (3), 431, 2004.

11. HAMMER M.J. Water and Wastewater Technology, $5^{\text {th }}$ ed.; Practice-Hall Inc.: Upper Saddle River, NJ, USA. 139, 2004.

12. MOHAMMED F.A.S. Histopathological studies on Tilapia zilliand Solea vulgarisfrom lake Quran, Egypt. World J. Fish Mar. Sci. 1, 29, 2009.

13. AUTHMAN M.M.N., ZAKI M.S., KHALLAF E.A., ABBAS H.H. Use of fish as Bio-indicator of the effects of heavy metals Pollution, J. Aquac. Res. Dev. 6, 328, 2015.

14. JALILOV S., KEFI M., KUMAR P. Sustainable urban water management: Application for integrated assessment in Southeast Asia. Sustainability, 10, 122, 2018. 
15. UN Water Annual Report 2008. Available online: http:// www.unwater.org/downloads/annualreport2008.pdf

16. MISHRA B.K., REGMI R.K., MASAGO Y., FUKUSHI K., KUMAR P., SARASWAT C. Assessment of Bagmati river pollution in Kathmandu Valley: Scenario-based modelling and analysis for sustainable urban development. Sustain. Water Qual. Ecol., 9, 67, 2017.

17. ANDERE GG W.R.L., KANE J.M., ANDEREGG L.D.L. Consequences of widespread tree Mortality triggered by drought and temperature stress. Nature Climate Change, 1 (3), 30, 2013.

18. DESTA M.B., ASGEDOM A.G., GEBREMEDHIN Y.W. Health risk assessment of heavy metals bioaccumulation in water, sediment and three fish species (Labeobarbus spp, Clarias gariepinus and Oreochromis niloticus) of Tekeze river dam, Tigray, Northern Ethiopia. J. Atm. Earth Environ. 1 (1) 19, 2012.

19. ADAIKPOH E.O., NWAJEI G.E., OGALA J.E. Heavy metals concentrations in coal and sediments from river Ekulu in Enugu, Coal City of Nigeria. J. Appl. Sci. Environ. 9 (3), 5, 2006.

20. TABINDA A.B., BASHIR S., YASER A., HUSSAIN M. Metals Concentrations in the Riverine Water, Sediments and Fishes from River Ravi at Balloki Headworks. J. Anim. Plant. sci. 23, 76, 2013.

21. IBEMENUGA K.N. Bioaccumulation and toxic effects of some heavy metals in freshwater fishes. Anim. Res. Int. 10 (3), 1792, 2013.
22. SHAKIR H.A., QAZI J.I., CHAUDHRY A.S., ALI S. Metal accumulation patterns in livers of major carps from anthropogenically affected segment of the river Ravi, Pakistan.Int. J. Adv. Res. Biol.Sci. 1, 261, 2014.

23. WAHEED S., MALIK R.N., JAHAN S. Health risk from as contaminated fish consumption by population living around River Chenab, Pakistan. Anim. Res. Int. 36 (2), 579, 2013

24. EL MOSELH K.H.M., OTHMAN A.L., EL-AZEM H.A., EL-METWALLYA M.E.A. Bioaccumulation of heavy metal in some tissue of fish in the Red Sea, Egypt. Egyption.J. basic.Appl.Sci. 1, 97, 2014.

25. QADIR A., MALIK R.S. Heavy Metal in Eight Edible Fish Species from Two Polluted Tributaries (Aik and Palkhu) of river Chenab, Pakistan.Biol.Trace.Elem.Res. 143, 1524, 2011.

26. AZMAT H., JAVED M. Acute Toxicity of Chromium to Catla catla, Labeo rohita and Cirrhina mrigala under Laboratory Conditions. Int J Agric Biol. 13, 961, 2011.

27. AZMAT H., JAVED M., JABEEN G. Acute toxicity of aluminum to the fish (Catla catla, Labeo rohita and Cirrhina mrigala). Pak. Vet. J. 32 (1), 85, 2012.

28. KARTHIKEYAN S. X-ray Diffraction and Fourier Transform Study of Toxic effect of Heavy metals on Bone Tissues of an Edible Fish Cirrhinus mrigala. Acta physica polonicaa. 122, 236, 2012.

29. SARAVANAN K, VEERAIYAN D.G., SUDARSANAM D., PRAVEENA P. Bioaccumulation of chromium in Cirrhinus mrigala. Int. J. Current. Res. 4, 079, 2012. 